\title{
Cytoprotective Effect of the Eryngium foetidum "Sacha Culantro" Methanolic Leaf Extract versus Sodium Fluoride Exposed Mice using the Micronucleus Test and the Comet Assay
}

\author{
Paola Raunelli ${ }^{1,2}$, Danae Liviac ${ }^{3}$, Rafael Alvis ${ }^{3}$, Silvio Puente ${ }^{4}$, Ivan Best ${ }^{1,5,6}$, Oscar Reátegui ${ }^{1,7, *}$
}

\section{Paola Raunelli ${ }^{1,2}$, Danae Liviac ${ }^{3}$, Rafael Alvis ${ }^{3}$, Silvio Puente $^{4}$, Ivan Best ${ }^{1,5,6}$ Oscar Reátegui ${ }^{1,7, *}$}

'Universidad Científica del Sur, Panamericana Sur Km 19, Lima, PERU. ${ }^{2}$ Medical School, Universidad Científica del Sur, Lima, PERU.

${ }^{3}$ Laboratory of Cellular and Molecular Biology, Universidad Científica del Sur, Lima, PERU.

${ }^{4}$ Nutrition and Dietetic School, Universidad Científica del Sur, Lima, PERU. ${ }^{5}$ Hersil S. A. Laboratorios Industriales Farmacéuticos, Lima, PERU.

${ }^{6}$ Grupo de Ciencia, Tecnología e Innovación en Alimentos, Universidad San Ignacio de Loyola, Lima, PERU. ${ }^{7}$ Agroforestry Engineering School, Universidad Científica del Sur, Lima, PERU.

\section{Correspondence}

MSc. Oscar Reátegui Arévalo

School of Agroforestry Engineering, Universidad Científica del Sur, Lima, PERÚ.

Phone no : +51 996676087

E-mail: oreategui@cientifica.edu.pe

\section{History}

- Submission Date: 20-09-2018

- Review completed: 12-12-2018;

- Accepted Date: 12-02-2019

DOI : 10.5530/pj.2019.11.72

Article Available online

http://www.phcogj.com/v11/i3

\section{Copyright}

(c) 2019 Pharmacognosy Journal. This is an open-access article distributed under the terms of the Creative Commons Attribution 4.0 International license.

\begin{abstract}
Introduction: Eryngium foetidum, commonly known as sacha culantro, is a plant that grows in the Peruvian Amazonian jungle, studied for its high concentration of antioxidant substances and various ethnopharmacological properties. The main goal of the study is to observe the cytoprotective and antioxidant effect of the extract from its leafs in Mus musculus previously administered with Sodium fluoride (NaF) using the Micronucleus test and the Comet assay. Methods: The extract was administrated orally in four different concentrations: 180, 360, $720,1440 \mathrm{mg} / \mathrm{Kg}$ for ten days, at the $11^{\text {th }}$ day a single dose of NaF was administrated via intraperitoneal at $20 \mathrm{mg} / \mathrm{Kg}$. The genotoxicity study was made with mice from the strain BALB/c, using the Micronucleus test on bone marrow and the Comet assay on peripheral blood according the OECD guides 474 and 489 respectively. The statistical analysis was made by the media's analysis with ANOVA. Results: Significant differences were found in Micronucleus frequency between the highest concentrations of Eryngium foetidum and NaF. The Comet assay showed significant reduction in $\mathrm{NaF}$ induced damage according to different concentrations of the extract. Conclusion: The Eryngium foetidum extract has cytoprotective activity against oxidant substances such as $\mathrm{NaF}$.

Key words: Eryngium foetidum, Cytoprotective, Micronucleus test, Comet assay, Toxicity, Genotoxicity.
\end{abstract}

\section{INTRODUCTION}

The Instituto de Investigaciones de la Amazonía Peruana (IIAP) reports that the Peruvian Amazonian jungle holds the greatest biological diversity worldwide, known by the medicinal components in the leafs of its plants. ${ }^{1}$ On 1993, the World Health Organization (WHO) reported that $80 \%$ of the world population draw on traditional medicine to assist their needs in primary care. Despite that, there is no true knowledge and sufficient research to use medicinal plants, such as dosage, plants species, etc.; they are even considered as primitive measurements. ${ }^{2}$

Eryngiun foetidum (EF), a medicinal plant commonly known in Perú as sacha culantro, from the family Apiaceae, is distributed in the Peruvian jungle and other places in America, some places of Asia like the east of India and Australia., ${ }^{3,4}$ Among the substances hold in its leafs there are a lot of bioactive compounds such as flavonoids, known for their activity on endothelium and their anti-inflammatory activity. ${ }^{5,6} \mathrm{EF}$ grows in several places of Perú and has been used by the native people of these areas based on traditional knowledge of its therapeutic effects, which also have drawn attention from researches across the globe. The major of these effects is based on traditional use,

experiments in vitro or on animal models but not on clinical trials, therefore there is no sufficient data for the human application. Some of the effects known are: anthelmintic, anti-convulsant, anti-inflammatory, analgesic, antimalarial and antibacterial, among others. $^{\text {? }}$

The flavonoids are substances widely studied for its anti-inflammatory effects, though they also may have pro-inflammatory effects, ${ }^{8}$ depending on the context in which they are used: concentration, physical factors and other chemical substances present such as metal ions, the most described is cupper. ${ }^{9}$ This anti-inflammatory activity, mainly based on the antioxidant activity, leads to various effects provided to the plants that contains them. Some researchers describe flavonoids as chemoprevention agents, with antimutagenic potential, with an important role in human health preservation. ${ }^{10}$ The use of natural substances to assess certain pathologies draws more attention in time, which comes with the impulse of agroindustrial activity for its pharmacological uses.

The study for genotoxicity can be made throughout some biological models such as the Micronucleus

Cite this article: Raunelli P, Liviac D, Alvis R, Puente S, Best I, Reátegui O. Cytoprotective Effect of the Eryngium foetidum "Sacha Culantro"Methanolic Leaf Extract versus Sodium Fluoride Exposed Mice using the Micronucleus Test and the Comet Assay. Pharmacog J. 2019;11(3):461-5. 
(MN) test and the Comet assay. ${ }^{11}$ The mammalian in vivo MN test's purpose is to identify substances that cause cytogenetic damage, which results in the formation of micronuclei on the studied cells, in this case the erythrocytes. ${ }^{11}$ The chosen cells are studied in the bone marrow, because their maturing progress consists on expulsing the nucleus, therefore any damage to the Deoxyribonucleic Acid (DNA), such as $\mathrm{MN}$, could be seen in this process, especially because the mature kind lack of nucleus. The in vivo alkaline Comet assay, is used to detect DNA strand breaks in cells under alkaline conditions, $p \mathrm{H}>13$; these breaks can be the result of direct interactions with DNA, sites of DNA that are alkali labile or as a consequence of transient DNA strand breaks resulting from DNA excision repair. ${ }^{12}$

Sodium fluoride is an inorganic salt used commonly on dental treatments to prevent caries, topically or in some cases in municipal water fluoridation systems. It has also been used as an insecticide, wood preservative, manufacture of glass and many other. ${ }^{13}$ It has also been used in cytotoxic research models, in high doses it has a very potent oxidative effect which damages directly on the DNA molecules. ${ }^{14}$ For example, it can break DNA brands and cause apoptosis in human cells, such as erythrocytes and generate oxidative stress on oral mucosa from rats. Among the main adverse reactions is the generation of free oxygen radical in cells. ${ }^{15}$

\section{MATERIALS AND METHODS}

\section{Methods}

This study was Analytic Experimental, was developed in the facilities from the Universidad Científica del Sur, Lima-Perú in the period March 2016-January 2018.

\section{Plant Material}

The plant of Eryngiun foetidum (20 kilograms) was collected from the Estación Experimental Forestal "A. von Humboldt" from the Instituto Nacional de Investigaciones Agrarias (INIA-Pucallpa) at Coronel Portillo- Ucayali, Perú (coordinates 8²3’00”S 74³3’00”O / -8.383333, -74.55) on June 2016. It was conditioned and then transported by plane to Lima. The plant was taxonomically authenthicated by Dr. Eloy Cuellar (Instituto Nacional de Investigaciones Agrarias-Puno).

\section{Experimentation Animals}

For the acute oral toxicity experiment: 6 male Hotzman albino rats weighing 180-190 g (6 - 8 weeks old) were divided in 2 groups, one being the control. For feeding balanced rodent special food was used and water ad libitum. Physical conditions were: temperature at $19.6^{\circ} \mathrm{C}$, humidity $67 \%$ and $12 \mathrm{~h}$ light/dark natural cycle.

For the micronucleus test and comet assay: 30 healthy, albino mice Mus musculus (BALB/c) between 6-10 weeks olds, weighing 25-35 g were supplied by the Instituto Nacional de Salud (Lima) seven days before the experiments. The animals were brought to the animal facilities of the university and kept in boxes in air-conditioned room $\left(23^{\circ} \mathrm{C}\right)$ and relative humidity of $50 \%$, with cycle of $12 \mathrm{~h}$ darkness/light and were fed with special balanced pellet (Universidad Agraria La Molina, Perú) and water ad libitum.

\section{Experimental Design}

\section{Extract Preparation}

The plants were cleaned and separated the leaf from the roots and left to dry, after that they were selected according size, color and if they had any damage, it was discarded. Then they were dried on a stove with forced air at $40^{\circ} \mathrm{C}$ for $72 \mathrm{~h}$, after that the sample was grounded and stored in amber glass jars. The Extract was made using the technic according Reichel et al. ${ }^{16}$ The grounded leafs were mixed with metha- nol to homogenization for $30 \mathrm{~min}$, then centrifugated at $18000 \mathrm{~g}$ for $5 \mathrm{~min}$. This procedure was performed twice to obtain the methanolic extract. Then the sobrenadant was purified by SPE and dried in a vacuum evaporator until to get the purified solid residue.

\section{Antioxidant Activity}

To determine the antioxidant capacity, three tests were performed

\section{- Ferric Reducing ability of plasma (FRAP)}

It was performed using the technic by Benzie and Strain (1996) modified by Szollozi, et al. One $\mathrm{mL}$ of the FRAP substance was mixed with $1 \mathrm{~mL}$ destilated water and the extract of sacha culantro, then exposed at $37^{\circ} \mathrm{C}$ for $15 \mathrm{~min}$ and read on the spectrophotometer $(539 \mathrm{~nm}) \mathrm{com}-$ pared with an standard curve with different concentrations of $\mathrm{Fe}^{+2}$

\section{- 2,2-Diphenil-1-picrilhidracil (DPPH)}

The technic used was proposed by Brand-Williams et al. described by Szydlwska-Czerniak et al. ${ }^{17}$ The mixed consisted on various concentrations of extract at $1 \mathrm{~mL}$ of acetate buffer $p \mathrm{H} 6(0.1 \mathrm{M})$, methanol and $0.5 \mathrm{~mL}$ of DPPH $0.1 \mathrm{mM}$, mixed and heated at $37^{\circ} \mathrm{C}$ for $30 \mathrm{~min}$ to be read on spectrophotometer $517 \mathrm{~nm}$. The control was made comparing with the solution of DPPH without the extract.

\section{- Thiobarbituric Acid Reactive Substances (TBARS)}

It was performed according the technic described by Draper $(1990)^{18}$ which evaluates the lipoperoxidation by measuring the formation of Malondialdehyde (MDA) using the reactive acid thiobarbituric on presence of acid trichloroacetic, then put at the spectrophotometer at $532 \mathrm{~nm}$.

\section{Determination of Flavonoids and Polyphenols}

According to the technic by Wolfe et al. ${ }^{19}$ for flavonoids determination, $205 \mu \mathrm{L}$ of methanolic extract was mixed with $125 \mu \mathrm{L}$ water and $75 \mu \mathrm{L}$ if sodium nitrate at $5 \%$. It was set for $5 \mathrm{~min}$ and then added trichloride of aluminum at $10 \%$. Set again for 6 min and added $0.5 \mathrm{~mL}$ sodium hydroxide $2 \mathrm{M}$ and $275 \mu \mathrm{L}$ water, then put at the spectrophotometer at $510 \mathrm{~nm}$. The technic for polyphenols determination was from Singleton and Rossi (1965) described by Naczk (2006). ${ }^{20}$ For the mixture, $1 \mathrm{~mL}$ of Folin-Ciocalteu solution at $10-\%$ and $0.1 \mathrm{~mL}$ of the extract were set for $5 \mathrm{~min}$, then added $1 \mathrm{~mL}$ of sodium carbonate at $7.5 \%$. Then $15 \mathrm{~min}$ at $45^{\circ} \mathrm{C}$ and read at spectrophotometer at $725 \mathrm{~nm}$.

\section{Acute oral toxicity}

According to the OECD guideline for testing chemicals $423,{ }^{20}$ the animals were treated and observed for 14 days. The treated group (3 rats) were fed with the extract at a concentration of $2000 \mathrm{mg} / \mathrm{Kg} / \mathrm{day}$ using an intragastric cannula and the control group (3 rats) with $1 \mathrm{~mL}$ distillated water. The animals were weighted at the beginning of the experiment, at the $7^{\text {th }}$ day and at the end; then they were sacrificed by cervical dislocation for the macroscopic organ analysis. During all the experiment (14 days), abnormal behavior was recorded.

\section{Genotoxicity study}

Following the OECD guidelines 474 for MN and 489 for Comet assay, ${ }^{11-12}$ the treatment lasted 10 days, the 30 animals were divided into 6 groups of 5 mice each ( 3 males and 2 females): the negative control group was administrated orally with the diluent DMSO $10 \%$ and no bioactive substances; the extract was administrated trough an intragastric cannula at different doses $180 \mathrm{mg} / \mathrm{Kg}, 360 \mathrm{mg} / \mathrm{Kg}$, $720 \mathrm{mg} / \mathrm{Kg}$ and $1440 \mathrm{mg} / \mathrm{Kg}$; the positive control group did not receive any substance until day 11 where all groups except negative control were administrated with a single dose of $\mathrm{NaF} 20 \mathrm{mg} / \mathrm{Kg}$ via intraperitoneal. The animals were observed for one more day until at day 12 were sacrificed by cervical dislocation. 


\section{Micronucleus Test}

After the sacrifice, the femur was removed for the extraction of bone marrow with physiological serum enriched with BSA $10 \%$ and centrifuged at $1500 \mathrm{rpm}$, the supernatant was disposed and the cellular sample was smeared to let dry and fixed with cold methanol. The slides were stained with Giemsa 2\% for the microscopic analysis at 1000x using a Nikon Eclipse 50i microscope. The OECD guideline 474 establishes the identification of MN cells: a principal nucleus and one or more nuclear structures named $\mathrm{MN}$, the $\mathrm{MN}$ is rounded or almond shaped and is $1 / 3-1 / 16$ from the main nucleus, it has the same intensity, texture and focal plane as the nucleus. Two-thousand polychromatic erythrocytes (1000 cell per replicate) were scored for each sample.

In addition, 500 cells (Polychromatic and normochromic erythroyctes) were scored to determinate the Cytotoxic Index (CTI). This index is used to evaluate the number of cells with DNA damage in comparison with the ones that did not present DNA alterations and could mature, having as a premise that genotoxic substances alter the polychromatic erythrocytes.

$$
\text { Cytotoxic index }(\mathrm{CTI})=\frac{\text { polychromatic erythrocyte }}{\text { normochromic erythrocyte }}
$$

\section{Comet Assay}

The comet assay was perfomed using the Guidelines by OECD Test 489 Alkaline Comet assay with minor modifications. Approximately $40 \mathrm{uL}$ of blood was resuspended in $110 \mathrm{ul}$ of $0.5 \%$ Low Melting Point Agarose (LMA), smeared on microscope slides pre-coated with $100 \mathrm{uL}$ of $0.5 \%$ Normal Melting Point Agarose (NMA) previously dried at $65^{\circ} \mathrm{C}$ and covered with a coverslip and kept at $4^{\circ} \mathrm{C}$ until solidification. The coverslips were removed and cells were lysed for $2 \mathrm{~h}$ at $4^{\circ} \mathrm{C}$ in a dark chamber containing a cold fresh lysing solution. To allow DNA denaturation, unwinding and exposure of alkali-labile sites, the slides were placed in a horizontal gel electrophoresis tank filled with cold electrophoresis solution for $20 \mathrm{~min}$. Electrophoresis was made in the same solution for $20 \mathrm{~min}$ at $0.73 \mathrm{~V} / \mathrm{cm}$ and $300 \mathrm{~mA}$. Then, the slides were neutralized with washes

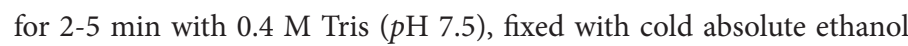
for $3 \mathrm{~min}$ and stored in the dark at room temperature. Before the microscope analysis, the slides were stained with $50 \mathrm{uL}$ of Hoescht 33258 (50 ug/mL), then observed at $400 \mathrm{X}$ magnification at a Nikon Eclipse 50i fluorescence microscope. One hundred randomly cells (50 cells from each of the two replicate slides) were analyzed per sample. These cells were visually analyzed according to classes, ranging from undamaged, score 0 (Completely undamaged; 0 x 100 cells) to highly damage, score 400 (Completely damaged; 4 x 100 cells).

\section{Statistical Analysis}

For the antioxidant activity the tests results were presented as medias from three determinations \pm Standard Deviation (SD). The differences between medias were determined by Kruskall-Wallis test. The correlations between variables was made by the Pearson test and ran through the program SPSS.
For the genotoxicity study, statistical analysis of medias from the different groups of the experiment was made using the ANOVA technic with the SPSS statistical program. The statistical significance was 95\%, $p<0,05$

The percentage reduction reflected the reduction of damage in comparison with the positive and negative control, ${ }^{21}$ seeing more objectively the cytoprotective effect of the plant extract.

$$
\operatorname{Reduction}(\%)=\left[\frac{\mathrm{A}-\mathrm{B}}{\mathrm{A}-\mathrm{C}}\right] \times 100
$$

A: the media of damage in positive control; B: the media of damage in the treatment group (Sacha culantro $+\mathrm{CP}$ ); $\mathrm{C}$ : the media of damage in the negative control.

\section{RESULTS}

\section{Antioxidant Activity}

The results found in the different tests made to determine the bioactive compounds and antioxidant capacity of the methanolic extract of sacha culantro leaf are shown in the Table 1.

Total polyphenols estimated using the Folin-Ciocalteu method, were found in a lower amount $(16.09 \mathrm{mg} \mathrm{GAE} / \mathrm{g})$. Flavonoid contens were also found in minor content $(3.58 \mathrm{mg} \mathrm{CE} / \mathrm{g})$. Although, Vukic et al. reported $311.11 \mathrm{mg} \mathrm{GAE} / \mathrm{g}$ and $154.98 \mathrm{mg}$ RUE (Rutine equivalents) for total polyphenols and flavonoid contents respectively in leaf methanolic extracts fron Eryngium serbicum L.

On the other hand, the antioxidant activity measure by DPPH method for methanolic extract was $0.8924 \mu \mathrm{mol}$ TEAC/g, meanwhile, Le Claire et al. reported $0.908 \mu \mathrm{mol}$ ascorbic acid /g extract of Eryngium alpinum. They concluded that their results indicate the position and/or the number of glycosyl groups present in the molecule plays a significant part in the antioxidant activity.

\section{Acute oral Toxicity Study}

Oral administration of EF extract not produce any mortality or abnormal behavioral response on rats during the 14 days of experiment. On the anatomopathological study, there were no organ or system alterations compared to the control group. The lethal dosis 50 (LD-50) for this extract appeared to be $>5000 \mathrm{mg} / \mathrm{kg}$.

\section{Genotoxicity Study}

According to the results shown in the Table 2, treatments of 180, 360,720 and $1440 \mathrm{mg} / \mathrm{kg}$ body weigh EF extract caused a significant decrease in the MNPCE frequency by $52.4 \%$ (9.00 \pm 0.707$), 67.9 \%$ $(6.40 \pm 1.817), 83.3 \%(3.80 \pm 0.837)$ and $97.6 \%(1.40 \pm 0.894)$, respectively compared to $\mathrm{NaF}$ exposure $(17.80 \pm 6.140)$, showing the protective capacity of the plant extract. Also, the results of the present study showed that the leaf extract of E. foetidum can mitigate the cytotoxicity of the $\mathrm{NaF}$ and promotes the erythropoiesis in mice. Like the results of the Micronucleus test, the data from comet analysis of peripheral blood erythrocytes in mice showed that all the doses evaluated were capable to reduce the $\mathrm{NaF}$ induced DNA damage.

Table 1: Bioactive compounds and Antioxidant Activity of Methanolic Extract leaf of Sacha Culantro.

\begin{tabular}{cccccc} 
& Polyphenols $(\mathrm{mg}$ GAE$/ \mathrm{g})$ & Flavonoids $(\mathrm{mg} \mathrm{CE} / \mathrm{g})$ & FRAP $\left(\mu \mathrm{mol} \mathrm{Fe} \mathrm{e}^{+2} / \mathrm{g}\right)$ & DPPH $(\mu \mathrm{mol}$ TEAC/g) & TBARS $(\mathrm{mg}$ MDA/g) \\
\hline Methanolic extract & $16.09 \pm 0.52$ & $3.58 \pm 0.121$ & $44.63 \pm 0.65$ & $0.8924 \pm 0.53$ & $19.60 .8924 \pm 0.56$ \\
\hline
\end{tabular}

GAE-Gallic acid equivalents; CE-Catechin equivalents; Data represented as means \pm SD $(n=3)$. 
Table 2: Genotoxicity Study: Micronucleus test and Comet assay.

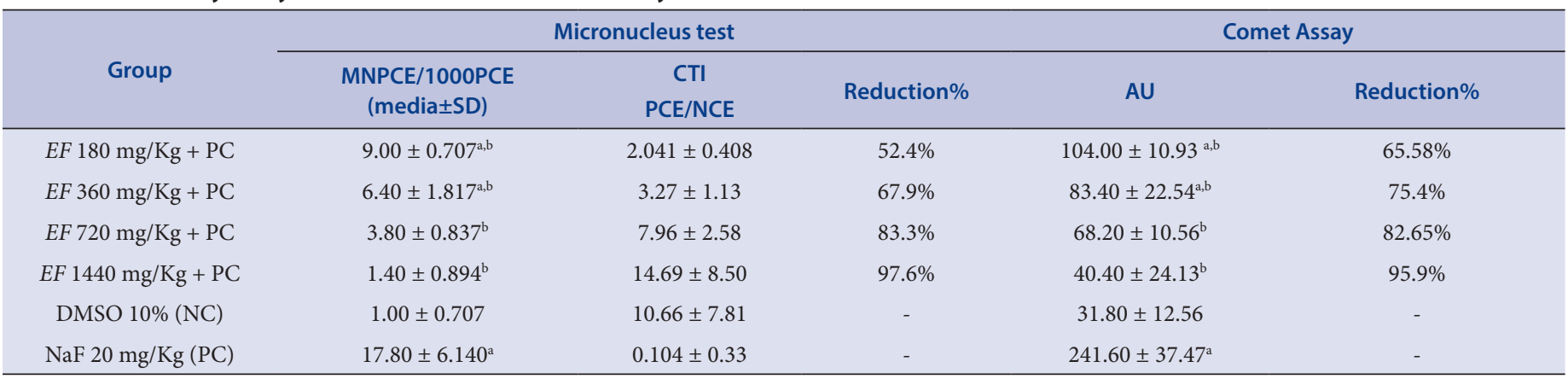

Each treatment contains 3 females and 2 males.

NC: Negative Control.

PC: Positive Control.

MN: Micronucleus, PCE: Polychromatic erythrocyte, NCE: Normochromic erythrocyte, CTI: cytotoxic index.

SD: Standard deviation.

Tukey's Parametric test.

${ }^{a}$ significant difference from the negative control $(p<0.05)$.

${ }^{\mathrm{b}}$ significant difference from the negative control $(p<0.05)$.

\section{DISCUSSION}

The study to determine the antioxidant capacity of the methanolic extract of sachaculantro was performed using the most important markers such as TBARS which measures the lipoperoxidation, meaning damage to lipid substances by free radicals; DPPH which measures specific free radicals and FRAP which measures the antioxidant effect by the reduced iron ions. These extracts demonstrated that it has very high levels of these markers, therefore a high antioxidant activity, related with the high concentration of polyphenols and flavonoids. These markers were compared with studies from Colombia ${ }^{7}$ and India $^{3}$ and they turned to have greater antioxidant capacity tan the extracts from other studies.

The evaluation for acute oral toxicity showed a LD-50 $2000 \mathrm{mg} / \mathrm{kg}$, which comes as no surprise because it is a solution almost purely composed by flavonoids and polyphenols and also it has been widely used by the native people by thousands of years with no apparent adverse reactions, also seen in the necropsy. This LD-50 is ranged on the $5^{\text {th }}$ category of the OECD which corresponds to extremely low toxicity and has low risk of toxic reactions when orally administrated..$^{22-23}$

The Micronucleus test and the Comet assay are two of the most reliable markers for mutagenic and teratogenic activity on cells with high mitotic activity and then the progression to carcinogenesis produced by some substances. They show the chromosomic damage, therefore genotoxicity, in this case in immature erythrocytes exposed to substances like sodium fluoride. This marker also provided information about the protector effect which some substances have on the DNA. In the results, a pattern is seen that as long as the concentration of the extract rises, the Micronucleus frequency and the damaged nucleotides drops. Placing this information on the formulas, the results have the same pattern on the reduction percentage getting almost to $100 \%$ on regard to the positive control. That means that the methanolic extract of sacha-culantro can protect from the damage to DNA made by some substances reducing it almost completely. Also, it can be seen with the cytotoxic index, which shows the capability of the cell to mature and more cells mature when they have higher concentration of the extract, meaning there was no DNA damaged, either for a successful reparation process or because there was no damage at all. This benefit can be explained because of the high antioxidant activity, in relation to the oxidant effect of sodium fluoride, which alters DNA by producing free radicals that affect the genetic material resulting in mutations.

\section{CONCLUSION}

In conclusion the methanolic extract of Eryngium foetidum has a cytoprotective effect against mutagenic substances such as Sodium fluoride. Also, this extract has proven to have very high antioxidant activity, a high concentration of flavonoids and polyphenols; and a very low index for acute oral toxicity, with a LD-50 of $2000 \mathrm{mg} / \mathrm{kg}$.

The study for antimutagenic substances should be performed widely, specially having products with low toxicity and low or non-adverse reactions. Therefore, a more specific study should be made to isolate the exact component from this extract that has the cytoprotective effect.

\section{ACKNOWLEDGEMENT}

The authors thank FONDECYT (Code: $\left.\mathrm{N}^{\circ} 151-2015\right)$ and Universidad Cientifica del Sur for helping to support this research.

\section{Financial support and sponsorship}

Nil.

\section{CONFLICT OF INTEREST}

There are no conflicts of interest.

\section{ABBREVIATIONS}

EF: Eryngium foetidum; NaF: Sodium fluoride; CTI: Cytotoxic index; PCE/NCE: Number of polychromatic erythrocyte/numbers of normochromic erythrocyte; CP: Cyclophosphamide; MNPCE: Polychromatic erythrocytes with micronuclei; FRAP: Ferric reducing antioxidant power; TBARS: Thiobarbituric acid reactive substances; LD50: Lethal doses 50 .

\section{REFERENCES}

1. Pinedo M, Rengifo ECT. Plantas Medicinales DeLaAmazonia Peruana. First Instituto Delnvestigaciones. Iquitos. 1997;201-2.

2. WHO, Uicn W. Directrices sobre conservación de plantas medicinales. In. 1996;1-34.

3. Singh S, Singh DR, Banu S, Salim KM. Determination of bioactives and antioxidant activity in Eryngium foetidum L: A traditional culinary and medicinal herb. Proc Natl Acad Sci India Sect B - Biol Sci. 2013;83(3):453-60.

4. Paul JH, Seaforth CE, Tikasingh T. Eryngium foetidum L.: a review. Fitoterapia $2011 ; 82(3): 302-8$. 
5. Mekhora C, Muangnoi C, Chingsuwanrote P, Dawilai S, Svasti S, Chasri K, et al. Eryngium foetidum Suppresses Inflammatory Mediators Produced by Macrophages. Asian Pacific J Cancer Prev. 2012;13(2):653-64.

6. Escamilla-Jiménez Cl, Cuevas-Martínez EY, Guevara-Fonseca J. Flavonoides y sus acciones antioxidantes. Fac Med UNAM. 2009;52(2):73-5.

7. Jaramillo BE, Duarte E, Martelo I. Volatile chemical composition of the essential oil from colombian Eryngium foetidum. and determination of its antioxidant a. Rev Cuba Plantas Med. 2011;16(2):140-50.

8. Yordi EG, Pérez EM, Villares EU, Matos MJ. Antioxidant and Pro-Oxidant Effects of Polyphenolic Compounds and Structure-Activity Relationship Evidence. Intech Open Access Publisher, Shanghai, China. 2012;23-48.

9. Eghbaliferiz S, Iranshahi M. Prooxidant Activity of Polyphenols, Flavonoids, Anthocyanins and Carotenoids: Updated Review of Mechanisms and Catalyzing Metals. Phyther Res. 2016;30(9):1379-91.

10. Stavric B. Antimutagens and anticarcinogens in foods. Food Chem Toxicol. 1994;32(1):79-90.

11. OECD. OECD Guideline for the Testing of Chemicals Tg 474 Mammalian erythrocyte micronucelus test. In: Oecd Guidelines. 2014;1-16.

12. OECD. Test No. 489: In vivo Mammalian Alkaline Comet Assay, OECD Guidelines for the Testing of Chemicals. OECD Publ. 2014;4:1-21.

13. Daston GP, Rehnberg BF, Carver B, Kavlock RJ. Toxicity of sodium fluoride to the postnatally developing rat kidney. Environ Res. 1985;37(2):461-74.

14. Arroyo-Acevedo JL, Herrera-Calderon O, Rojas-Armas JP, Chumpitaz-Cerrate V Franco-Quino C, et al. Chuquiraga spinosa Lessing: A Medicinal Plant for Gastric Cancer Induced By N-Methyl-N-Nitroso-Urea (NMU). Pharmacognosy Journal. 2018;10(1):20-4.

15. Gutiérrez-Salinas J, Morales-Gonzalez JA. Sodium fluoride ingestion induced oxidative stress in buccal mucosa in rat. Rev Mex Ciencias Farm. 2006;37(3).

16. Reichel M, Carle R, Sruamsiri P, Neidhart S. Changes in flavonoids and nonphenolic pigments during on-tree maturation and postharvest pericarp browning of litchi (Litchi chinensis Sonn.) as shown by HPLC-MSn. J Agric Food Chem.
$2011 \cdot 59(8) \cdot 3924-39$

17. Szydłowska-Czerniak A, Bartkowiak-Broda I, Karlovic I, Karlovits G, Szłyk E. Antioxidant capacity, total phenolics, glucosinolates and colour parameters of rapeseed cultivars. Food Chem. 2011;127(2):556-63.

18. Draper HH, Hadley M. Malondialdehyde determination as index of lipid Peroxidation. Methods Enzymol. 1990;186(C):421-31.

19. Wolfe KL, Liu RH. Structure-activity relationships of flavonoids in the cellular antioxidant activity assay. J Agric Food Chem. 2008;56(18):8404-11.

20. Naczk M, Shahidi F. Phenolics in cereals, fruits and vegetables: occurrence, extraction and analysis. J Pharm Biomed Anal. 2006;41(5):1523-42.

21. OECD. OECD Guideline for testing of chemicals. Acute oral toxicity-acute toxic class method, guideline no. 423. Adopted 2001 Organization for Economic Cooperation and Development, Rome 2001. 2001;1-14.

22. Almora-Pinedo Y, Arroyo-Acevedo J, Herrera-Calderon O, Chumpitaz-Cerrate, $V_{\text {, }}$ Hañari-Quispe R, Tinco-Jayo A, et al. Preventive effect of Oenothera rosea on $\mathrm{N}$-methyl-N-nitrosourea-(NMU) induced gastric cancer in rats. Clin Exp Gastroenterol. 2017; 10:327-32.

23. Herrera-Calderon O, Alvarado-Puray C, Arroyo-Acevedo JL, Rojas-Armas JP, Chumpitaz-Cerrate V, Hañari-Quispe R, et al. Phytochemical screening, total phenolic content, antioxidant and cytotoxic activity of five peruvian plants on human tumor cell lines. Pharmacognosy Res. 2018;10(2):161-5.

24. Enciso-Roca E, Aguilar-Felices EJ, Tinco-Jayo JA, Arroyo-Acevedo JL, HerreraCalderon O, Aguilar-Carranza C, et al. Effects of Acute and Sub-acute Oral Toxicity Studies of Ethanol Extract of Tanacetum parthenium (L) Sch. Bip. Aerial Parts in Mice and Rats. Annu Res Rev Biol. 2017;19(2):1-10.

\section{GRAPHICAL ABSTRACT}

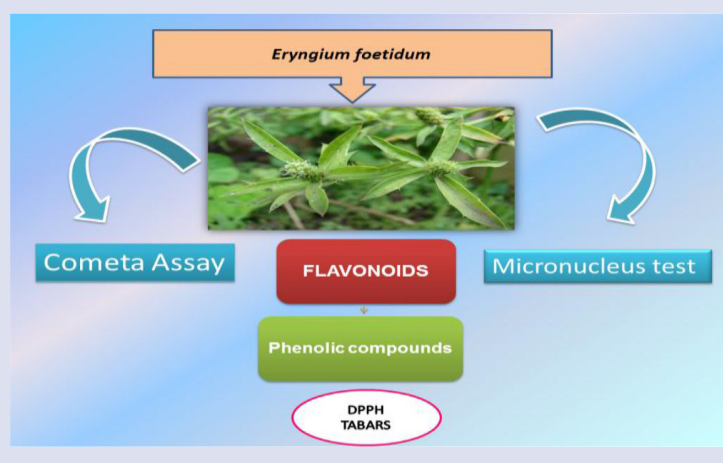

\section{SUMMARY}

- The extract of Eryngium foetidum was administrated orally in four different concentrations, at the $11^{\text {th }}$ day a single dose of $\mathrm{NaF}$ was administrated to evidence cytoprotective effect.

- The results demonstrated the cytoprotective potential of E. foetidum extract against two different types of DNA damage.

- The extract showed very high antioxidant activity, a high concentration of flavonoids and polyphenols; and a very low index for acute oral toxicity, with a LD-50 of $2000 \mathrm{mg} / \mathrm{kg}$.

Cite this article: Raunelli P, Liviac D, Alvis R, Puente S, Best I, Reátegui O. Cytoprotective Effect of the Eryngium foetidum "Sacha Culantro"Methanolic Leaf Extract versus Sodium Fluoride Exposed Mice using the Micronucleus Test and the Comet Assay. Pharmacog J. 2019;11(3):461-5. 